\title{
Mediating Effects of Governance on Audit Culture, Internal Control and Audit Quality in Indonesia: Basis for Model
}

\author{
LENNY LEORINA EVINITA ${ }^{1}$, JOSEPH PHILIP KAMBEY ${ }^{2}$ \\ ${ }^{1}$ Faculty of Economy, MANADO STATE UNIVERSITY, INDONESIA, \\ E-mail: lennyevinta@unima.ac.id \\ ${ }^{2}$ Faculty of Economy, MANADO STATE UNIVERSITY, INDONESIA, \\ E-mail: josephkambey@unima.ac.id
}

\begin{abstract}
The purpose of the research was to investigate the mediated effect of governance on audit culture, internal control and audit quality in in selected Indonesia Ministries and Agencies for the yar 2019 and found a new model. The research was conducted in a quantitative approarch. This study investigated the condition of audit quality in Indonesia, particularly: audit reliability, accuracy, professional ethics awareness, competence, value of recommendation among 422 full-time employees in the Ministries and agencies. Questionnaires were used to gather information. SPSS 23 was used to analyze the data for descriptive, correlational, and predictive purposes, as well as to establish the effect of the respondents' profile. Structural Equation Model for mediation was also utilized. The result indicated that audit culture and internal control have a positive relation to audit quality. Furthermore, the finding showed that the respondent's sex and educational attainment were not significantly different as regards to the perceptions of the respondent's about audit quality. As a result of this current study, a new model emerged which indicates that governance partially mediated internal control and audit quality. Further, the result also showed that audit culture has a direct effect on audit quality.
\end{abstract}

Keywords: Governance; Audit Culture; Internal Control; Audit Quality.

JEL Classification: M40, M42, 016

Received: June 18, 2021

Accepted: September 21, 2021 


\title{
Efectos Mediadores de la Gobernanza en la Cultura de la Auditoría, el Control Interno y la Calidad de la Auditoría en Indonesia: Bases del Modelo
}

\author{
LENNY LEORINA EVINITA ${ }^{1}$, JOSEPH PHILIP KAMBEY ${ }^{2}$ \\ ${ }^{1}$ Faculty of Economy, MANADO STATE UNIVERSITY, INDONESIA, \\ E-mail: lennyevinta@unima.ac.id \\ ${ }^{2}$ Faculty of Economy, MANADO STATE UNIVERSITY, INDONESIA, \\ E-mail: josephkambey@unima.ac.id
}

\begin{abstract}
RESUMEN
El objetivo de la investigación era investigar el efecto mediador de la gobernanza en la cultura de la auditoría, el control interno y la calidad de la auditoría en los ministerios y organismos de Indonesia seleccionados para el año 2019 y encontrar un nuevo modelo. La investigación se llevó a cabo con un enfoque cuantitativo. Este estudio investigó la condición de la calidad de la auditoría en Indonesia, en particular: la fiabilidad de la auditoría, la precisión, la conciencia de la ética profesional, la competencia, el valor de la recomendación entre 422 empleados a tiempo completo en los ministerios y organismos. Se utilizaron cuestionarios para recopilar información. Se utilizó el SPSS 23 para analizar los datos con fines descriptivos, correlacionales y predictivos, así como para establecer el efecto del perfil de los encuestados. También se utilizó el modelo de ecuaciones estructurales para la mediación. El resultado indicó que la cultura de auditoría y el control interno tienen una relación positiva con la calidad de la auditoría. Además, los resultados mostraron que el sexo y el nivel educativo de los encuestados no eran significativamente diferentes en lo que respecta a las percepciones de los encuestados sobre la calidad de la auditoría. Como resultado de este estudio, surgió un nuevo modelo que indica que la gobernanza medió parcialmente en el control interno y la calidad de la auditoría. Además, el resultado también mostró que la cultura de auditoría tiene un efecto directo sobre la calidad de la auditoría.
\end{abstract}

Palabras clave: Gobernanza; Cultura de auditoría; Control interno; Calidad de la auditoría.

Clasificación JEL: M40, M42, O16

Recibido: 18 de Junio de 2021

Aceptado: 21 de Septiembre de 2021 


\section{Introduction}

Audit quality is indicated by compliance with audit standards so that the reliability of the employee's work can be sustained. By having a good quality result means that the organization follows the standard of measuring all the activities related to auditing. Currently, each country has audit standards towards commitment of delivering quality services. Lychs (2014) in his research which was conducted in listed companies around the world specifically, six largest accounting firms, found out that there were issues related to the audit evaluation, fair value, internal control and assessment of financial statements presented by public. Media has raised questions on perceived audit failure, the function of the auditor, quality of audits and the responsibilities of the auditors on delivering their duties. The audit quality considers reviewing policies/law according to international standards to represent the effectiveness of government auditor (Lee et al. 2016). Cases of scandals in financial report in the international level has indicated how weak the modern economy is and the effect it can cause on the effective performance of audit activities. This has been experienced in the corporate world such as in Exxon oil spill, the Enron fiasco in management and governance as well as in leadership (De Cremer et al. 2011). DeFond and Zhang (2014) explained that "the higher the audit quality is the greater the guarantee of high financial reporting quality. Audit quality adds assessment to market participants by providing assurance that financial statements faithfully reflect a company's underlying economic". The good audit quality can bring successful conclusion on the financial statement and this will mean that the client's financial statements are reliable and show the economic performance (Lee \& Lee, 2013). Intervention by political parties, which is a difference in practice and actuality, also influenced the audit quality. The head of the Executive arm of the government who is the President has the authority to control all bureaucracy in all public institutions including courts, police, audit boards and this affected the autonomous status of most of the government agencies (Muhammadi, 2016). Lonsdale and Wilkins (2011) agreed that auditing had the important role to make sure that government gives accountability report for the use of public resources. The confidence and clear accountability system will lead to strong transparency in public sector governance especially in democratic governments (Ian, 2011). Irawan (2015), in his study, outlined a research gap observed in performance audit quality in Indonesia. He found out that there was a need to have a new approach to improve public accountability, design, and construct appropriate systems that allow decisions which promote productivity and transparency. This can be done through the improvement of the performance auditing process and strengthening the institutional system at the Supreme Audit Institution and the administration through the Public Accounts Committee. The auditors are aware of the substantial aspect in performance auditing and work towards reframing the way performance auditing should be undertaken while there is little attention paid by the Parliament on the follow-up of audit reports (Irawan, 2015). Culture begins by an individual interacting with others and building their human behaviour. They try to set rules, routines and norms that guide and enforce behaviour. "Culture" is the principle of desirability, faiths and as a fundamental for an organization's management system. The principles must be practiced. Culture is shared by a group of people and is part of life that develops and is passed down from generation to generation. Culture is created by various aspect including religion, custom, language, politic system and artwork (Kurniawan, 2018). The quality of organizational performance in terms of productivity and profitability can be influenced by the organizational culture. Organizational sustainability is influenced by how the employees behave within the organization (Hellriegel \& Slocum, 2011). Hofstede's theory (1991) states the five dimensions of culture: (1) Power distance, (2). Individualism, (3) Masculinity, (4). Uncertainty avoidance and (5). Time orientation. Power is a basic concern of the ability of a human group being able to influence behaviour so that it exactly fits to the desire of the actor who has power. Each organization has a person to make the decision for all activities. Power distance happens in the organization because of functional authority and not because of the position of the individual. The beginning of power rests with the achievement and skill of the individual in authority. Power distance can be demonstrated by a large communication gap between superiors and their subordinates (Hofstede, 2014). Masculinity in the society is defined as an alternative to 
show one's achievement, firmness and reward for success. Women are more likely to perform a variety of tasks; they contribute modestly and are more likely to be equal to males.

Masculinity are measures which represent how the male and female typically feature and differ in a society (Orr \&Hauser, 2008). Culture tolerates future uncertainty, which is linked to uncertainty avoidance. When the culture has a high uncertainty avoidance and a low tolerance for uncertainty and attempt to plan for and predict the future. Individuals tend to prefer jobs that have stability and is referred to the persons that have a high uncertainty avoidance culture. This can also affect higher stress, emotionality, anxiety, neuroticism and poor self-control. Therefore, usually the companies/organization with high uncertainty avoidance would plan the action and strategies to avoid or mitigate the risk while the companies/organization with low uncertainty avoidance are willing to tolerate high risk and uncertainty (Hofstede, 2014). Merchant et al. (2011) also mentioned that time orientation includes past, present and future orientation. Attitude towards the past refers to past orientation and present orientation means to aim on attention at immediate events in themselves and diminished concern for, or interest in future consequences. Internal control was used to develop overall business process in organization using COSO framework. To have a good internal control, the management needs to do four things which are defining business objectives, recognizing the risks to reach those objectives, knowing how to manage the identified risks and setting up control on how to manage risk. Internal control can be said to be effective when it continues to address the objectives of the organization (COSO, 2013). Control environment is the foundation of carrying out internal control. The framework component of control environment is mostly concerned with outsourcing and ineffective in the arrangement. Even though an organization has set a good leader and communicate through mission statement, codes of conduct, etc. Risk assessment is the formation of objectives that the organization needs to set within categories of operations, reporting and compliance with sufficient clarity to enable the identification and analysis of risk. Risk assessment is required and should be considered by management while looking at the external influence which impacts the objectives of the internal control effectiveness in the organization. The task of management is to ensure the risk tolerance is included in the organization's practice and to avoid the future risk as risk can change based on the internal and external environment (COSO, 2013). Control activities consider the overall goal and the business process. They are designed to determine the effectiveness of the current process and to indicate the presence of fraud. Goals must be measured, and risk must be assessed by creating report with effective criteria of evaluation for measuring success or risk. Management override of control is a common element in many fraud issues, and it shows how to control over transaction and gives policies and procedure that can be defeated by wilful action by the executive and senior management (COSO, 2011). Studies pointed out that the treatment of the risks could be through recognizing the response strategy towards risk and the control activities enforced to be correctly defined report to specific risk that have been controlled. Activities assure the control of risks until reasonable. Communication is the continuous process of passing information along inside the organization and obtaining it outside. Communication also links the company's current and strategic objectives with the innovation potential for its development. Communication is about the extent of discussion on the evidence of the source of information and especially when information is used to support reporting objectives to the external parties. Some of the discussions on the impact of managerial necessities on the reliability and safety of information include checking of the impact of era and different communications mechanisms on the velocity and the first-rate of the movement of records (COSO, 2013). The idea in monitoring actives are organization pick out, perform and compare the aspect of the inner manage is exercising. The organization needs to evaluate and communicate internal control shortage and make corrective action for all staff including senior management and board of directors. Absences of internal control affect the monitoring activities in the organization by worsening and need to proactively identify the problems concerning the validity of financial report (COSO, 2013). Governance term is used to state the political field and political activity as the basis of responsibility of every national government. Governance is including in all the process of governing attempted by governments. This related to the process of interaction 
and decision making within organization, governance as one of the way rules, norms and actions are structured, regulated and held liable. Governance capability is to make and enforce rules and give services. Governance includes the institutions and structures of the states, decision making, capacity to the laws and the relationship between government officials and the public (Ebrahim \& Mair, 2014). Mayntz, (2017) stated that quality of governance is needed for the action to be effectiveness and not merely efficiency driven since this can lead to good governance driven goal/purpose. According to Global Development research Center (1996) governance dimension are: (1) Political, (2). Economic.

Obeid (2018) in his research by using empirical data from Asia stated that political security has an important role in resolving the economic progress. Organization politics can also lead to positive result including increased capacity of the organization, organizational development, increased communication and higher innovation (Landells \& Albrecht, 2017). Good governance improves long term development. At country level, good governance has a positive effect on the national economic situation, referred to as economic growth. According to Boediono (2016) when the government has dominance in economic system and have relationship in controlling the economy, all the behaviour or activities of the economy are regulated by the government. Economic dimension needs to have auditing service to enable them to have relevant informative value of account in the hands of those using it. In a research conducted in Tunisia the result was that economic growth positively influenced the effectiveness of the government, by controlling the government policies, administration quality, misuse government spending etc. (Amaira, 2019). The ability of auditors to acquire sufficient suitable audit evidence to provide an opinion on whether financial statements are properly prepared, which includes all material required under applicable financial reporting frameworks. Audit quality used to measure of implementation of auditor professional duties and duty and how well a job is finished compared to predetermined criteria (IAASB, 2014). The reliability in financial reporting system is important to give information to all stakeholders about financial information system, public interest to pay attention and secure proper operational of systems. The right financial information needs to support the auditor by having as correct audit evidence which can support the audit process. The factors that influences the reliability of audit evidence are when the auditor maintain from independent sources, the audit evidence maintain directly by the auditor. The auditor should keep the document, whether on paper or electronically, to observe the application of control (Ashfag, 2018). Financial audit is designed to support a reasonable assurance over the accuracy of financial statements, and it is important for the auditor to be conversant with the accuracy of all balance sheet items in financial statement and the disclosure of other appropriate information by the management. The auditors' behaviour is compelled by the notion of professional ethics auditors' behaviors to act by carefully examining something especially in a critical way (Sikka, 2009). Auditors have a duty to comply with high standard of behaviour in terms of their job and related to the staff of audited entities. Integrity is the core value of code of ethics as an auditor. Integrity can be determined in terms of what is right and just. Integrity requires the auditors to recognize both the principle of independence and objectivity and maintain standards of professional conduct. Professional ethics influences the audit report judgment and it displays the ability of the auditor to perform. Another factor which is connected to professional ethic of auditor are such as audit independence and relations between auditor and client (Salleh \& Jasmani, 2014). According to Subsomboon and Intakun (2015) high audit value has a positive relationship with all outcome of the resource audit continues learning and professional ethics awareness. Competence is the professional expertise possessed by the auditor through formal education, professional examination and joining the training, seminars, and symposiums. Auditor competency is evaluated by the number of certificates held and the number of participation in all audit activity.

\section{Statement of the Problems}

This study aimed to determine the mediating effects of governance on audit culture, internal control and audit quality of auditors in Indonesia. The result will serve as a basis for a proposed model. This research sought to answer the following questions: 
1. What is the extent of audit culture in terms of power distance,individualism, masculinity, uncertainty avoidence and time orientation?

2. What is the extent of internal control system in terms of control environment, risk assessment, control activities, information and communication, monitoring?

3. How do respondents perceive governance in terms of political and economic?

4. What is the level of audit quality in term of audit reliability, accurancy, professional ethics awareness, competence, value of recommendation?

5. Is there a significant relationship between the following variables
a) Audit culture and governance
b) Internal control and governance
c) Audit culture and audit quality
d) Internal control and audit quality
e) Governance and audit quality

6. Is there a significant difference in audit quality when the following variables are considered?
a) Sex
b) Educational attainment

7. Which among the following variables predict audit quality?
a) audit culture
b) Internal Control
c) Governance

8. Does governance mediate the relationship between audit culture, internal control and audit quality?

9. What is the model that can be developed based on the finding of the study?

\section{Research Method}

The researcher used a self-structured and partly adopted questionnaire to gather all the relevant data that were used in this study. The research used a proposive sampling, and the sample size calculated used Raosoft SurveyWin 3.2 tool and found 303 respondents, but the researcher distributed 422 questionnairs and 406 were retrieved indicating a $96.68 \%$ retrieval rate. To check the reliability of the questionnaire, the researcher used Cronbach's $\alpha$ to measure the internal consistency of the variable constructed from questionnaire items. Five Linkets scale are considered to measurement scale of question. The data gathered was analyzed using the Statistical Package of Social Sciences (SPSS) and Structural Equation Modeling. Regression analysis was used to find out predictors of intention to seek help and predictors of in terim of audit quality. One-way ANOVA and T-test were used to examine if audit quality practices of the respondents significantly differ when the demographic profile are considered. Structural Equation Modeling (SEM) was used to find out if intention to seek help mediate the effect of the independent.

\section{Results and Discussion}

\subsection{Audit Culture}

The table 1 presents the 6udit culture. Gudit6on the grand mean of $3.86(S D=0.37)$, the results reveal that the internal auditors' Gudit culture is verbally interpreted as strong. It implies that the Gudit culture is Gudi in terms of power distance, individualism, masculinity, uncertainty avoidance, time orientation. This finding is related to the article of Institute Internal Auditor (2013) that stated Gudit culture for the line management needs to improve in communication, set an example of the value and behaviour which the organization expects. The 6udit culture supports the organization because it refers to a created assumption, which is accepted as a way of doing things and passed to new members of the organization (Ledimo, 2015). 
Organizational culture needs to have a positive mental health workplace, the leadership team should consider having a systematic means of their culture, aligned with their goals in the workplace. The mental health policy should describe commitment to promoting and monitoring the culture in the organization (Ginter, 2018).

Table 1 Audit Culture

\begin{tabular}{lcccc}
\hline & M & SD & SR & VI \\
\hline Power Distance & 3.74 & .41 & Often & Strong \\
Individualism & 3.94 & .45 & Often & Strong \\
Masculinity & 3.91 & .44 & Often & Strong \\
Uncertainty Avoidance & 3.90 & .54 & Often & Strong \\
Time Orientation & 3.80 & .50 & Often & Strong \\
\hline Grand Mean and SD for Audit culture & 3.86 & .37 & Often & Strong \\
\hline
\end{tabular}

\subsection{Internal Control}

The table 2 presents the Internal Control. Based on the grand mean, 4.01(SD=.53), the results reveal that the ministries and agencies internal control is scaled at often and is verbally interpreted as good. This implies that internal control is good in terms of control environment, risk assessment, control activities, information and communication, monitoring. These results are in line with the study of Hermanson et. al, (2012) who stated that internal control relatively affects high improvement specially in appraising the top management. Good internal control requires the management to have business objectives, to identify the risks in achieving such objectives, to manage the risk and to establish control to manage the risks (COSO, 2013; ICAN, 2015).

Table 2 Internal Control

\begin{tabular}{lcccc}
\hline Internal Control & M & SD & SR & VI \\
\hline Control Environment & 4.23 & .62 & Often & Good \\
Risk Assessment & 4.08 & .56 & Often & Good \\
Control Activities & 3.90 & .59 & Often & Good \\
Information and Communication & 3.88 & .64 & Often & Good \\
Monitoring & 3.96 & .63 & Often & Good \\
\hline Grand Mean and SD for Internal Control & 4.01 & .53 & Often & Good \\
\hline
\end{tabular}

\subsection{Governance}

The table 3 present the Governance. Based on the grand means of 3.96 (SD=.54), the results reveal that the ministries and agencies governance is verbally interpreted as good. The result implies that governance is good in terms of economic dimensions and often in terms of political dimensions. This means that there is a set of rules that govern relations with other internal and external interest regarding rights and obligations. In other words, the system that directs and controls the organization is good and up to standard. Good governance can be interpreted as a way of regulating and controlling the organization in order to provide added value for the organization. Accordingly, the relationship between governance and performance can be from performance to governance rather than from governance to performance. Therefore, to attain good governance, there is a need of effectiveness not only efficiency driven to achieve the goal/purpose the company has (Saxena, 2005).

Table 3 Governance

\begin{tabular}{lccll}
\hline & M & SD & SR & VI \\
\hline Political & 3.97 & .58 & Often & Good \\
Economic & 3.95 & .67 & Often & Good \\
\hline Grand Means and SD For Governance & $\mathbf{3 . 9 6}$ & $\mathbf{. 5 4}$ & Often & Good \\
\hline
\end{tabular}




\subsection{Audit Quality}

The table 4 present audit quality. Based on the grand mean of $4.19(\mathrm{SD}=.50)$, the results reveal that the respondent grand scale response is often, and it is interpreted as good. The result implies that audit quality is good in terms of audit reliability, accuracy, professional awareness, competence, value of recommendation. Audit quality is good if the organization/institution which had been audited implemented the recommendation and maintains a process and information system to monitor the status of follow-up on the examiner's recommendation.

Audit is a process to reduce the misalignment of information that exists between leader/manger and shareholders by using outsiders to provide endorsement of the financial statements. To have a good audit quality the auditor needs to follow the auditing standard and code of ethics (UU PER/05/M. A. N/03/2008; IAASB, 2014)) Qualified auditors are the persons who can provide accurate information, which can show value of company.

Table 4 Audit Quality

\begin{tabular}{lllll}
\hline & M & SD & SR & VI \\
\hline Audit reliability & 4.26 & .56 & Often & Good \\
Accuracy & 4.30 & .53 & Often & Good \\
Professional Ethics Awareness & 4.22 & .65 & Often & Good \\
Competence & 4.01 & .59 & Often & Good \\
Value of Recommendation & 4.17 & .58 & Often & Good \\
\hline Audit Quality & $\mathbf{4 . 1 9}$ & $\mathbf{. 5 0}$ & Often & Good \\
\hline
\end{tabular}

4.5. Correlation Results of Audit Culture and Governance

Table 5 Correlation of Audit Culture to Governance

\begin{tabular}{lllll}
\hline & & Politics & Economic & Governance \\
\hline Power Distance & Pearson Correlation & $.121^{*}$ & $.295^{* *}$ & $.248^{* *}$ \\
& Sig. (2-tailed) & .015 & .000 & .000 \\
& VI & $\mathrm{NS}$ & $\mathrm{S}$ & $\mathrm{S}$ \\
Individualism & Pearson Correlation & $.267^{* *}$ & $.378^{* *}$ & $.378^{* *}$ \\
& Sig. (2-tailed) & .000 & .000 & .000 \\
Masculinity & VI & $\mathrm{S}$ & $\mathrm{S}$ & $\mathrm{S}$ \\
& Pearson Correlation & $.287^{* *}$ & $.409^{* *}$ & $.408^{* *}$ \\
& Sig. (2-tailed) & .000 & .000 & .000 \\
Uncertainty & VI & $\mathrm{S}$ & $\mathrm{S}$ & $\mathrm{S}$ \\
Avoidance & Pearson Correlation & $.368^{* *}$ & $.454^{* *}$ & $.479^{* *}$ \\
& Sig. (2-tailed) & .000 & .000 & .000 \\
Time Orientation & VI & $\mathrm{S}$ & $\mathrm{S}$ & $\mathrm{S}$ \\
& Pearson Correlation & $.306^{* *}$ & $.514^{* *}$ & $.483^{* *}$ \\
& Sig. (2-tailed) & .000 & .000 & .000 \\
Audit Culture & VI & $\mathrm{S}$ & $\mathrm{S}$ & $\mathrm{S}$ \\
& Pearson Correlation & $.350^{* *}$ & $.527^{* *}$ & $.515^{* *}$ \\
& Sig. (2-tailed) & .000 & .000 & .000 \\
& VI & $\mathrm{S}$ & $\mathrm{S}$ & $\mathrm{S}$ \\
\hline
\end{tabular}

The table 5, correlation of power distance to governance indicated that power distance had a positive Pearson correlation of .248 ( $p$-value $=.00$ ) which is significant at 0.01 ( 2 tailed). This shows that there is a positive correlation between power distance and governance. Based on the results, it was identified that power distance was influenced by governance performance and is expected from 
the ministries and agencies of study. Organization and internal audit will behold stakeholder expectation and implies their activities to include culture as integral element of audit process (Ramamoorti et al. 2018). Culture assessment consider clearly articulate code of conduct, organization culture emerges as powerful influence on the organization ability to follow rule of good governance (Chambers, 2016).

Culture is a collection of knowledge, beliefs, arts, morals, laws, custom and capabilities and habits that are obtained by a person as member of a particular association or community. Good governance and high integrity of culture will be start from the shareholders or stakeholder of the organization. The leaders, staff when did the daily operation of the company must have mutual trust with member of board of director, executives and employee to carry out governance that is truly honest, transparent, fair, responsible, professional and ethical towards all stakeholders. If the governance can express the culture of the organization it will create ethical governance, then the level of trust of minority shareholders or individuals will be the foundation that strengthens organization competitive advantage.

\subsection{Correlation result of Audit Culture and Audit Quality}

The table 6 shows the correlation of audit culture to audit culture. The results found out that the correlation of audit culture and audit quality has a positive Pearson correlation of $.658(\mathrm{p}$-value $=$ 0.000 ) or $0.658, p<.000$ which was found to be significant. This implies that there is significant relationship between audit culture with audit quality. This finding showed that audit culture is the core or center of the organization/institution exercise that has an impact on the organization effectiveness. Audit culture is important to organization and its effect on audit habit/practices as it brings about organization plan of competence service. This shows that audit culture has positive significant correlation with audit quality. Based on the result, it was identified that high audit culture influence audit quality in ministries and agencies.

Table 6 Correlation Audit Culture and Audit Quality

\begin{tabular}{|c|c|c|c|c|c|c|c|}
\hline & & AR & ACC & PEA & COMP & VOR & $\mathbf{A Q}$ \\
\hline \multirow[t]{2}{*}{ Power Distance } & $\begin{array}{l}\text { Pearson } \\
\text { Correlation }\end{array}$ & $.277^{* *}$ & $.194^{* *}$ & $.266^{* *}$ & $.349^{* *}$ & $.278^{* *}$ & $.319^{* *}$ \\
\hline & Sig. (2-tailed) & .000 & .000 & .000 & .000 & .000 & .000 \\
\hline \multirow[t]{2}{*}{ Individualism } & $\begin{array}{l}\text { Pearson } \\
\text { Correlation }\end{array}$ & $.431^{* *}$ & $.351^{* *}$ & $.405^{* *}$ & $.437^{* *}$ & $.493^{* *}$ & $.493^{* *}$ \\
\hline & Sig. (2-tailed) & .000 & .000 & .000 & .000 & .000 & .000 \\
\hline \multirow[t]{2}{*}{ Masculinity } & $\begin{array}{l}\text { Pearson } \\
\text { Correlation }\end{array}$ & $.408^{* *}$ & $.353^{* *}$ & $.441^{* *}$ & $.510^{* *}$ & $.526^{* *}$ & $.523^{* *}$ \\
\hline & Sig. (2-tailed) & .000 & .000 & .000 & .000 & .000 & .000 \\
\hline \multirow[t]{2}{*}{$\begin{array}{l}\text { Uncertainty } \\
\text { Avoidance }\end{array}$} & $\begin{array}{l}\text { Pearson } \\
\text { Correlation }\end{array}$ & $.534^{* *}$ & $.415^{* *}$ & $.578^{* *}$ & $.499^{* *}$ & $.578^{* *}$ & $.609^{* *}$ \\
\hline & Sig. (2-tailed) & .000 & .000 & .000 & .000 & .000 & .000 \\
\hline \multirow[t]{2}{*}{$\begin{array}{l}\text { Time } \\
\text { orientation }\end{array}$} & $\begin{array}{l}\text { Pearson } \\
\text { Correlation }\end{array}$ & $.514^{* *}$ & $.398^{* *}$ & $.539^{* *}$ & $.550^{* *}$ & $.603^{* *}$ & $.609^{* *}$ \\
\hline & Sig. (2-tailed) & .000 & .000 & .000 & .000 & .000 & .000 \\
\hline \multirow[t]{2}{*}{ Audit Culture } & $\begin{array}{l}\text { Pearson } \\
\text { Correlation }\end{array}$ & $.559^{* *}$ & $.442^{* *}$ & $.577^{* *}$ & $.600^{* *}$ & $.639^{* *}$ & $.658^{* *}$ \\
\hline & Sig. (2-tailed) & .000 & .000 & .000 & .000 & .000 & .000 \\
\hline
\end{tabular}




\subsection{Correlation of interanl control and Governance}

The table 7 showed that there was significant relationship between internal control and governance .780, $p=0.000$ as show in Table (7) To answer the question hypothesis number one $\mathbf{b}$ : There is no significant relationship between internal control and governance, the correlation of internal control and governance has positive Pearson correlation of .780 ( $p$-value-0.000) or $0.780, p<.000$, based on the result there is significant relationship between internal control with governance. Internal auditor limited their role in verifying compliance with the connected laws and regulation rather than adopt a consulting role, and governance by verifying the effectiveness of internal control contribution to governance practices (Koutoupis, Pazarskis, \& Drogalas, (2018). The organization/institution had a long-term sustainability shareholders and stakeholder need to consider a good governance. Internal audits help the organization to achieve its objectives, through a systematic and regular approach to managing and improving the effectiveness of risk management control and processes governance. The role of internal audit will be increasingly reliable in developing and maintaining the effectiveness of internal control systems, risk management and good governance.

Table 7 Correlation of internal control and governance

\begin{tabular}{|c|c|c|c|c|}
\hline & & Politics & Economic & Governance \\
\hline \multirow{2}{*}{$\begin{array}{l}\text { Control } \\
\text { Environment }\end{array}$} & Pearson & $.447^{*}$ & $.592^{* *}$ & $.608^{* *}$ \\
\hline & Sig. (2-tailed) & .000 & .000 & .000 \\
\hline \multirow[t]{2}{*}{ Risk Assessment } & $\begin{array}{l}\text { Pearson } \\
\text { Correlation }\end{array}$ & $.488^{* *}$ & $.681^{* *}$ & $.685^{* *}$ \\
\hline & Sig. (2-tailed) & .000 & .000 & .000 \\
\hline \multirow[t]{2}{*}{ Control Activities } & $\begin{array}{l}\text { Pearson } \\
\text { Correlation }\end{array}$ & $.506^{* *}$ & $.676^{* *}$ & $.692^{* *}$ \\
\hline & Sig. (2-tailed) & .000 & .000 & .000 \\
\hline \multirow[t]{2}{*}{$\begin{array}{l}\text { Information and } \\
\text { Communication }\end{array}$} & $\begin{array}{l}\text { Pearson } \\
\text { Correlation }\end{array}$ & $.494^{* *}$ & $.714^{* *}$ & $.709^{* *}$ \\
\hline & Sig. (2-tailed) & .000 & .000 & .000 \\
\hline \multirow[t]{2}{*}{ Monitoring } & $\begin{array}{l}\text { Pearson } \\
\text { Correlation }\end{array}$ & $.463^{* *}$ & $.722^{* *}$ & $.697^{* *}$ \\
\hline & Sig. (2-tailed) & .000 & .000 & .000 \\
\hline \multirow[t]{2}{*}{ Internal Control } & $\begin{array}{l}\text { Pearson } \\
\text { Correlation }\end{array}$ & $.551^{* *}$ & $.779^{* *}$ & $.780^{* *}$ \\
\hline & Sig. (2-tailed) & .000 & .000 & .000 \\
\hline
\end{tabular}

\subsection{Correlation of Audit culture and Audit Quality}

The table 8. Shows the results foundout that the correlation of audit culture and audit quality has a positive Pearson correlation of .658 ( $p$-value $=0.000$ ) or $0.658, p<.000$ which was found to be significant. This implies that there is significant relationship between audit culture with audit quality. This finding showed that audit culture is the core or center of the organization/institution exercise that has an impact on the organization effectiveness. Audit culture is important to organization and its effect on audit habit/practices as it brings about organization plan of competence service. The study of Svanberg and Öhman (2013) is in contrast with this study. The result shows that ethical culture is negatively connected to reduce audit quality act. 
Table 8 Correlation of Audit Culture and Audit Quality

\begin{tabular}{|c|c|c|c|c|c|c|c|}
\hline & & AR & ACC & PEA & COMP & VOR & $\mathbf{A Q}$ \\
\hline \multirow[t]{2}{*}{$\begin{array}{l}\text { Power } \\
\text { Distance }\end{array}$} & $\begin{array}{l}\text { Pearson } \\
\text { Correlation }\end{array}$ & $.277^{* *}$ & $.194^{* *}$ & $.266^{* *}$ & $.349^{* *}$ & $.278^{* *}$ & $.319^{* *}$ \\
\hline & Sig. (2-tailed) & .000 & .000 & .000 & .000 & .000 & .000 \\
\hline \multirow[t]{2}{*}{ Individualism } & $\begin{array}{l}\text { Pearson } \\
\text { Correlation }\end{array}$ & $.431^{* *}$ & $.351^{* *}$ & $.405^{* *}$ & $.437^{* *}$ & $.493^{* *}$ & $.493^{* *}$ \\
\hline & Sig. (2-tailed) & .000 & .000 & .000 & .000 & .000 & .000 \\
\hline \multirow[t]{2}{*}{ Masculinity } & $\begin{array}{l}\text { Pearson } \\
\text { Correlation }\end{array}$ & $.408^{* *}$ & $.353^{* *}$ & $.441^{* *}$ & $.510^{* *}$ & $.526^{* *}$ & $.523^{* *}$ \\
\hline & Sig. (2-tailed) & .000 & .000 & .000 & .000 & .000 & .000 \\
\hline \multirow[t]{2}{*}{$\begin{array}{l}\text { Uncertainty } \\
\text { Avoidance }\end{array}$} & $\begin{array}{l}\text { Pearson } \\
\text { Correlation }\end{array}$ & $.534^{* *}$ & $.415^{* *}$ & $.578^{* *}$ & $.499^{* *}$ & $.578^{* *}$ & $.609^{* *}$ \\
\hline & Sig. (2-tailed) & .000 & .000 & .000 & .000 & .000 & .000 \\
\hline \multirow[t]{2}{*}{$\begin{array}{l}\text { Time } \\
\text { orientation }\end{array}$} & $\begin{array}{l}\text { Pearson } \\
\text { Correlation }\end{array}$ & $.514^{* *}$ & $.398^{* *}$ & $.539^{* *}$ & $.550^{* *}$ & $.603^{* *}$ & $.609^{* *}$ \\
\hline & Sig. (2-tailed) & .000 & .000 & .000 & .000 & .000 & .000 \\
\hline \multirow[t]{2}{*}{ Audit Culture } & $\begin{array}{l}\text { Pearson } \\
\text { Correlation }\end{array}$ & $.559^{* *}$ & $.442^{* *}$ & $.577^{* *}$ & $.600^{* *}$ & $.639^{* *}$ & $.658^{* *}$ \\
\hline & Sig. (2-tailed) & .000 & .000 & .000 & .000 & .000 & .000 \\
\hline
\end{tabular}

\subsection{Correlation of internal control and audit quality.}

The table 9 shows the correlation of internal control to overall audit quality. The correlation of internal control and audit culture has a positive Pearson correlation of .730 ( $p$-value-0.000) which was found to be significant. This implies that there is a significant relationship between internal control and audit culture. Internal auditor limits their role in verifying compliance with the connected laws and regulation rather than adopt a consulting role, and governance by verifying the effectiveness of internal control contribution to governance practices (Koutoupis, et.al, 2018).

Table 9 Correlation of Internal Control and Audit Quality

\begin{tabular}{|c|c|c|c|c|c|c|c|}
\hline & & AR & ACC & PEA & Comp & VOR & $A Q$ \\
\hline \multirow[t]{2}{*}{$\begin{array}{l}\text { Control } \\
\text { Environment }\end{array}$} & $\begin{array}{l}\text { Pearson } \\
\text { Correlation }\end{array}$ & $.550^{* *}$ & $.562^{* *}$ & $.503^{*}$ & $.440^{*}$ & $.545^{* *}$ & $.603^{* *}$ \\
\hline & & .000 & .000 & .000 & .000 & .000 & .000 \\
\hline \multirow[t]{2}{*}{$\begin{array}{l}\text { Risk } \\
\text { Assessment }\end{array}$} & $\begin{array}{l}\text { Pearson } \\
\text { Correlation }\end{array}$ & $.623^{* *}$ & $.590^{* *}$ & $.589^{*}$ & $.530^{*}$ & $.583^{* *}$ & $.678^{* *}$ \\
\hline & & .000 & .000 & .000 & .000 & .000 & .000 \\
\hline \multirow[t]{2}{*}{$\begin{array}{l}\text { Control } \\
\text { Activities }\end{array}$} & $\begin{array}{l}\text { Pearson } \\
\text { Correlation }\end{array}$ & $.594^{* *}$ & $.543^{* *}$ & $.579^{* *}$ & $.584^{* *}$ & $.534^{* *}$ & $.660^{* *}$ \\
\hline & Sig. ( & .000 & .000 & .000 & .000 & .000 & .000 \\
\hline \multirow{2}{*}{$\begin{array}{l}\text { Information } \\
\text { \&Communica } \\
\text { tion }\end{array}$} & $\begin{array}{l}\text { Pearson } \\
\text { Correlation }\end{array}$ & $.591^{* *}$ & $.528^{* *}$ & $.542^{*}$ & $.526^{*}$ & $.522^{* *}$ & $.630^{* *}$ \\
\hline & Sig. (2-tailed) & .000 & .000 & .000 & .000 & .000 & .000 \\
\hline \multirow[t]{2}{*}{ Monitoring } & $\begin{array}{l}\text { Pearson } \\
\text { Correlation }\end{array}$ & $.561^{* *}$ & $.541^{* *}$ & $.503^{*}$ & $.494^{*}$ & $.523^{* *}$ & $.609^{* *}$ \\
\hline & Sig. (2-tailed) & .000 & .000 & .000 & .000 & .000 & .000 \\
\hline \multirow[t]{2}{*}{$\begin{array}{l}\text { Internal } \\
\text { Control }\end{array}$} & $\begin{array}{l}\text { Pearson } \\
\text { Correlation }\end{array}$ & $.671^{* *}$ & $.635^{* *}$ & $.624^{*}$ & $.591^{*}$ & $.622^{* *}$ & $.730^{* *}$ \\
\hline & Sig. (2-tailed) & .000 & .000 & .000 & .000 & .000 & .000 \\
\hline
\end{tabular}




\subsection{Correlation of Governance and Audit Quality}

The table 10 show the correlation of governance and audit quality. The correlation of governance and audit quality has a positive Pearson correlation of .735( $p$-value-0.000) which was found to be significant. This implies that there is significant relationship between governance and audit quality.

The effectiveness of governance will give a high concentration of ownership and less demand to extensive auditing; it needs to be concerned about governance, audit fee (Alqadasi \& Abidin, 2018). Good governance can provide better external condition for audit quality; the auditor needs to have better professional skill and keep independence and competence (Peng, 2010). Better governance also gets high level audit quality (Habib \& Jian,2015).

Table 10 Correlation of Governane and Audit Quality

\begin{tabular}{|c|c|c|c|c|c|c|c|}
\hline & & AR & ACC & PEA & Comp & VOR & $A Q$ \\
\hline \multirow[t]{2}{*}{ Politics } & $\begin{array}{l}\text { Pearson } \\
\text { Correlation }\end{array}$ & $.524^{* *}$ & $.515^{* *}$ & $.545^{* *}$ & $.403^{* *}$ & $.474^{* *}$ & $.573^{* *}$ \\
\hline & Sig. (2-tailed) & .000 & .000 & .000 & .000 & .000 & .000 \\
\hline \multirow[t]{2}{*}{ Economic } & $\begin{array}{l}\text { Pearson } \\
\text { Correlation }\end{array}$ & $.616^{* *}$ & $.551^{* *}$ & $.590^{* *}$ & $.588^{* *}$ & $.611^{* *}$ & $.688^{* *}$ \\
\hline & Sig. (2-tailed) & .000 & .000 & .000 & .000 & .000 & .000 \\
\hline \multirow[t]{2}{*}{ Governance } & $\begin{array}{l}\text { Pearson } \\
\text { Correlation }\end{array}$ & $.664^{* *}$ & $.619^{* *}$ & $.659^{* *}$ & $.582^{* *}$ & $.634^{* *}$ & $.735^{* *}$ \\
\hline & Sig. (2-tailed) & .000 & .000 & .000 & .000 & .000 & .000 \\
\hline
\end{tabular}

\subsection{Difference in Audit Quality Considering Demographics Sex}

The table 11 show the difference in audit quality in term of sex. The finding there is no significant difference in audit quality when sex is considered. This result is supported by an investigation done by Montenegro et. al (2015), who said that the audit firm with female-dominated partnership structure are not related with aggressive accounting practices in audit client

Table 11 Difference in Audit Quality Considering Demographic Sex

\begin{tabular}{|c|c|c|c|c|c|c|}
\hline & $\begin{array}{l}\text { Sex of } \\
\text { Respondent }\end{array}$ & $N$ & Mean & T Test & $\begin{array}{l}\text { Sig.(2- } \\
\text { tailed) }\end{array}$ & VI \\
\hline \multirow[t]{2}{*}{ Audit reliability } & Male & 214 & 4.2857 & 1.111 & .269 & NS \\
\hline & Female & 192 & 4.2240 & & & \\
\hline Accuracy & Male & 214 & 4.3171 & & & \\
\hline Accuracy & Female & 194 & 4.2775 & .755 & .451 & NS \\
\hline Professional Ethics & Male & 214 & 4.2891 & & & \\
\hline Awareness & Female & 194 & 4.1488 & 2.205 & .028 & Sig \\
\hline \multirow[t]{2}{*}{ Competence } & Male & 214 & 4.0592 & 1.604 & .110 & NS \\
\hline & Female & 192 & 3.9653 & & & \\
\hline \multirow{2}{*}{$\begin{array}{l}\text { Value of } \\
\text { Recommendation }\end{array}$} & Male & 214 & 4.1911 & .843 & .400 & NS \\
\hline & Female & 192 & 4.1424 & & & \\
\hline
\end{tabular}

\subsection{Education Attainment}

The table 12 show the difference in audit quality in term of education. The respondents are grouped according to educational attainment. The result shows the difference in audit quality when educational attainment is considered. This finding is in contrast with the research conducted by Van et.al (2019) which stated that education has an influence or impact on working motivation. Education affect all aspects of individual personality and life. Likewise, Hanushek and Woessmann (2011) found in their 
research that years of education completed, highest qualification achieved and on individual actual competences are considered better measures of individual human capital.

Table 12 Education Attainment

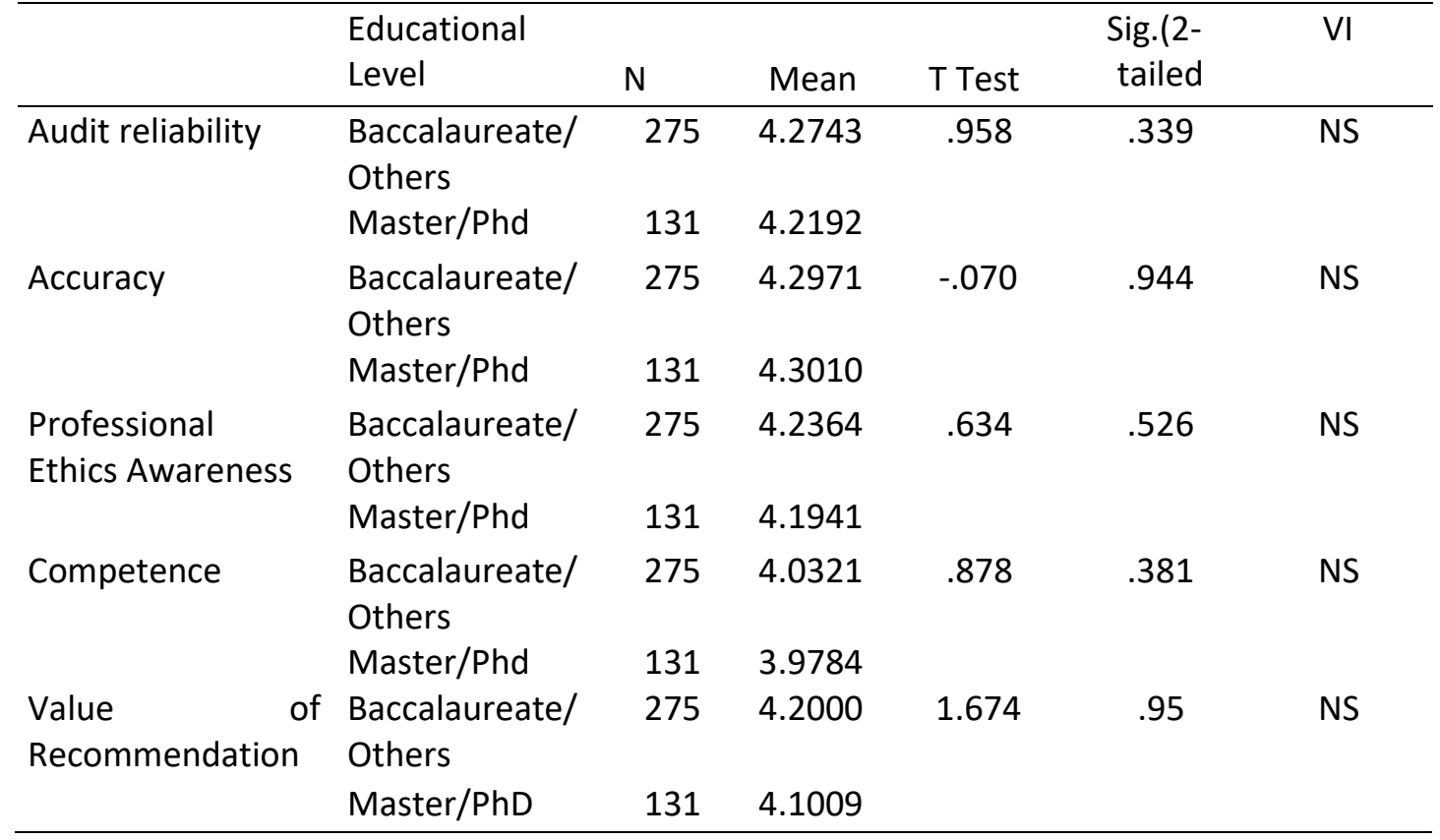

\subsection{Predictor in term of audit quality}

The table 13 show the predictor in term of audit quality. The predictive results, the explained variable on audit quality are economic dimensions with $47 \%$; uncertainty avoidance, $11 \%$; political dimensions, $5 \%$; risk assessment, $3 \%$; time orientation, $1 \%$; masculinity, $1 \%$; and control environment is $1 \%$. However, there are $31 \%$ variables which were not considered in this study but can explain audit quality in Indonesia. The proposed applied model based on the unstandardized beta for this study is $A Q=.33+.17 \mathrm{E}+.15 \mathrm{UA}+.18 \mathrm{P}+.15 \mathrm{RA}+.14 \mathrm{TO}+.11 \mathrm{M}+.10 \mathrm{CE}$

Table 13 Predictor in term of Audit Quality

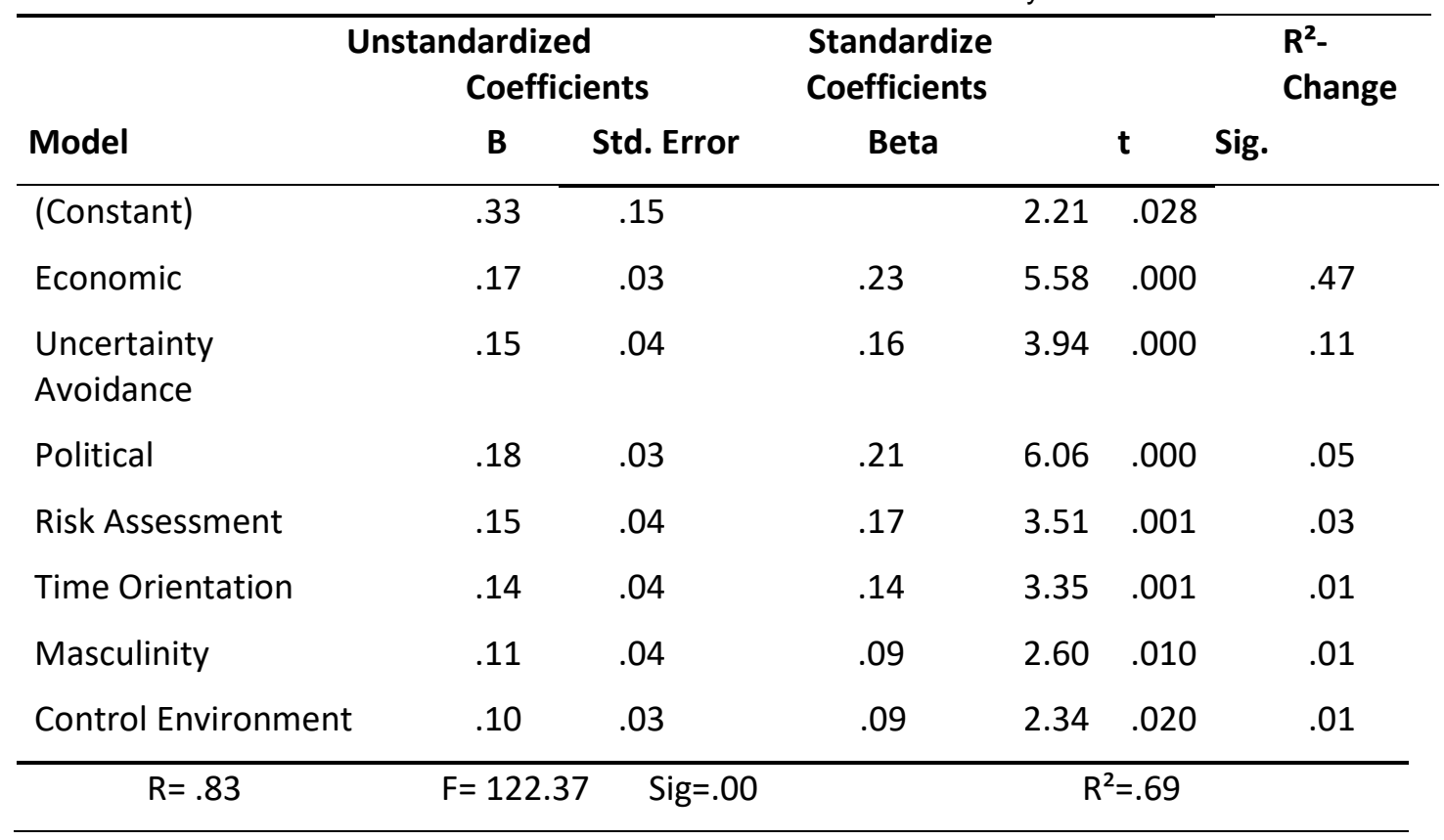




\subsection{Mediating Effects of Governance on Audit Culture}

The measurement model is used to describe the latent variable by forming relationships or using a structural equation model with it (Schumacher \& Lomaz, 2010). The results was found that Internal control is directly related to audit quality and is mediated by governance with a direct effect of (.41) and indirect effect of $\left(.16^{*} .68=.1088\right)$ which relate to audit quality; the total effect of $\left(.41+\left(.16^{*} .68\right)\right)$ $=.52$ or $52 \%$ and direct effect of audit culture support $41 \%$ increase on audit quality made it significant. Labor unions have high expectations for audit quality and system internal control (Bryan, 2015). Governance structure is an important factor for internal control auditing report disclosure (Li, 2011).

\section{New model Evaluation}

After editing the model, it shows that the variables such as audit culture and internal control had direct effect to audit quality and are partially mediated by governance. Here are the sub-hypotheses considered in political and economic aspects based on the new model's result: The impact of internal control on audit quality was mediated by governance. The sub-hypothesis a, which was offered as a result in the table (14) stated that governance mediates internal control on audit quality. The result agreed with the hypothesis showing the positive effects of governance $(\alpha \times \beta=$ $.110, p$-value $<.36$ ) and that governance partially mediates internal control on audit quality.

Figure 1 Final Model Result using AMOS

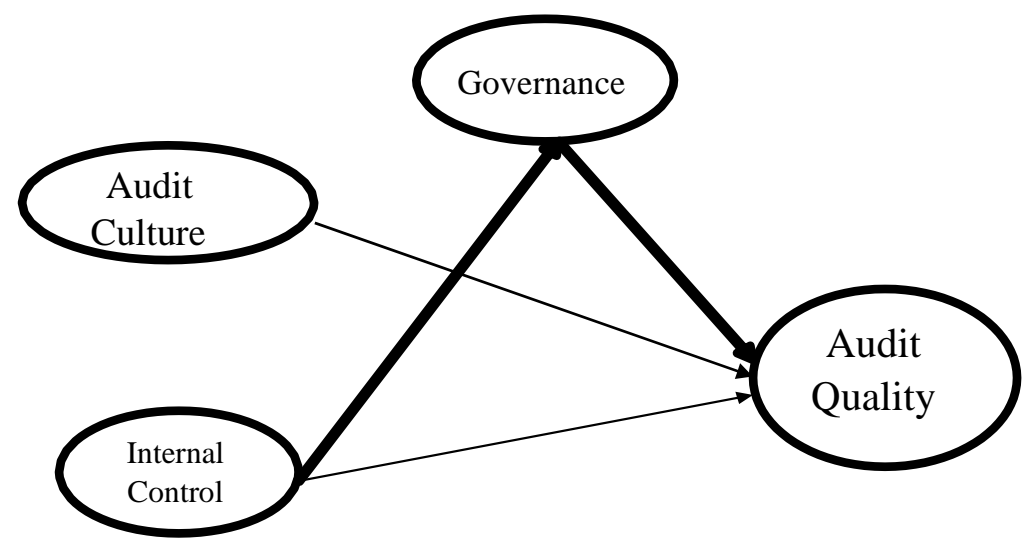

Table 14 Audit Quality Model

\begin{tabular}{llllllll}
\hline Id & Independent & Dependent & Mediator & Type & Estimate & p-value & VI \\
\hline 1 & Internal & Audit & Governance & Partially & 0.11 & 0.036 & $\mathrm{~S}$ \\
& Control & Quality & & & & & \\
\hline
\end{tabular}

\section{Conclusion}

Based on the results of the study, the following conclusions were made; Audit culture, internal control as independent variables and governance as mediating variables were found to be factors that influence audit quality. Sex and educational attainment as moderator variables have no significant difference in audit quality in terms of audit reliability and accuracy, professional ethics awareness, competence and value of recommendation. Internal control is significantly related to governance. One of the dimensions of governance in terms of political dimensions partially mediated internal control on audit quality. Finally, 7 out of 19 dimensions from audit culture, internal control, governance, demographic variable significantly predicted audit quality. The best predictor were found to be economic, uncertainty avoidance, political, risk assessment, time orientation, masculinity, control environment. Each of the dimension had a p-value of .00, .00, .00, .001, .001, .010 and.020 
respectively. Therefore, the hypothesis that state that governance does not mediate audit culture, internal control and audit quality is rejected. This implies that audit culture has direct effects on audit quality while internal control is partially mediated by governance on audit quality.

\section{Limitations and further research}

The respondents of the study were limited to only organizations with the highest number of employees assuming those with fewer employees. Future researchers are advised to explore other independent variables that affect audit quality in ministries/agencies. Therefore, it is recommended that other variables such as moral development be considered as an exogenous variable to solve audit quality. It is also recommended that future researcher undertake similar studies in profit organization/business setting.

\section{References}

1. Amaira, B. (2019). Analysis of the relationship between governance and economic growth: new evidence from tunisia an ARDL bounds testing approach. Magallat Al-Tanmiyat Wa-Al-Siyasat Allqtisadiyyat, 21(1), 21-37. Retrieved from https://search. proquest.com/docview/2254447288?accountid=42729.

2. Ashfag, A (2018) "What are the factor which influence the reliability of audit evidence, https://www.bayt.com/en/specialties/q/268263/what-are-the-factors-which- influence-thereliability-of-audit-evidence/..

3. AlQadasi, A., \& Abidin, S. (2018). The effectiveness of internal corporate governance and audit quality: The role of ownership concentration Malaysian evidence. Corporate Governance,18(2),233253. doi: http://dx.doi.org/10.1108/CG-02-2017-0043.

4. Boediono, (2016). 'Managing the Indonesian economy: some lessons from the past', Bulletin of Indonesian Economic Studies, 41(3):309324.

5. Chambers, R. F. (2016). When culture is the culprit. Directorship, 65-66. Retrieved from https://search. proquest.com/docview/1802715710?accountid $=42729$.

6. COSO (Committee of Sponsoring Organizations of the Treadway Commission). (2011) http://controlsframework.com/coso_images.php.

7. COSO (2013) Internal Control - Integrated Framework, Executive Summary,

Framework and Appendices, Illustrative Tools for Assessing Effectiveness of a System of Internal Control, Available at: http://www.coso.org/ic.htm.

8. De Cremer, Rolf van Dick, Ann Tenbrunsel, Madan Pillutla, \& J. Keith Murnighan (2011). Understanding Ethical Behavior and Decision Making In Management. British Journal of Management, Vol. 22, S1-S4 (2011).

9. DeFond, M., \& Zhang, J. (2014). A review of archival auditing research. Journal of Accounting \& Economics, 58(2/3), 275-326. doi:10. 1016/j.jacceco.2014.09.002.

10.Ginter, P. A. (2018). Conducting a mental health culture audit. Benefits Magazine, 55(5), 40 Retrieved from https://search. proquest.com/docview/2078625000?accountid=42729

11.Habib, A., \& Jiang, H. (2015). Corporate governance and financial reporting

quality in China: A survey of recent evidence. Journal of International Accounting, Auditing and Taxation, 24, 29-45.

12. Hanushek EA, Woessmann L. (2011). The economics of international differences in educational achievement. Handbook of the economics of education, chap 2. Elsevier, pp 89-192.

13. Hellriegel, D., and Slocum, J. (2011). Organizational Behavior, 13th ed. South Western: Cengage Learning.

14. Hermanson, D., Smith, D., \& Stephens, N. (2012). How effective are organizations' internal controls? Insights into specific internal control elements. Current issues in auditing, 6(1), A31- A50

15. Hofstede, G. H. (2001). Culture's Consequences: Comparing values, behaviors, institutions, and organizations across nations. Thousand Oaks, CA: Sage. 
16. Hofstede, G. (2011). Dimensionalizing cultures: The Hofstede model in context. Online Readings in Psychology and Culture, 2(1). Retrieved from dx.doi.org/10.9707/2307-0919.1014.

17. Hofstede Centre (2014), accessed 25 April 2013.available at http://www.cultureready.org/blog/cultural-tools-hofstede-center.

18.IAASB (International Auditing and Assurance Standards Board). (2014). Available at: https://www.iaasb.org/.

19.Ian B, (2011). IFAC CEO, in CIPFA's 1st International Conference: Trust and Accountability in Public Financial Management, March, 17 2011, London

20.ICAN., (2015). Audit planning and control. The Institute of Chartered Accountants of Nigeria. http://icanig.org/documents/aaa.pdf, (May 15, 2015)

21.Irawan, B Agus, 2015. Evaluation of performance auditing in Indonesia: A critical systemic approach to addressing public accountability, pp. 282-283.

22.Kurniawan, A. (2018), Pengertian Budaya Menurut Para Ahli Beserta Definisi Dan Unsurnya, available at: https://www.gurupendidikan.co.id/pengertian-budaya- menurut-para-ahli-besertadefinisi-dan-unsurnya.

23.Koutoupis, A., Pazarskis, M., \& Drogalas, G. (2018). Auditing corporate governance statements in greece - the role of internal auditors. Corporate Governance,18(5), 1007-1020. doi: http://dx.doi.org/10.1108/CG-02-2018-0095.

24.Landells, E. M., \& Albrecht, S. L. (2017). The positives and negatives of organizational politics: A qualitative study. Journal of Business and Psychology, 32(1), 41-58. doi: http://dx.doi.org/10.1007/s10869-015-9434-5.

25.Lee, S. C., Su, J. M., Tsai, S. B., Lu, T. L., \& Dong, W. (2016). A comprehensive survey of government auditors' self-efficacy and professional Development for improving audit quality. SpringerPlus,5(1), 1263.

26.Lee, H.L. and Lee, H. (2013), "Do Big 4 audit firms improve the value relevance of earnings and equity?" Managerial Auditing Journal, Vol. 28 No. 7, pp. 628-646.

27.Ledimo, O. (2015). Diversity management: An organisational culture audit to determine individual differences. Journal of Applied Business Research, 31(5), 1747.

Retrieved from https://search.proquest.com/docview/1777990739?accountid=42729

28.Lonsdale, J., Wilkins, P. \&Ling, T. (2011). Performance Auditing Contributing to Accountability in Democratic Government. Cheltenham: Edward Elgar.

29.Lychs Sarah, (2014). Audit around the world are riddled with problem-survey, Retrieved from https://www.reuters.com/article/regulations-auditor-survey/audits-around-the-world-areriddled-with-problems-survey-idUSL1NOMWOS520140410.

30.Mayntz, R. (2017). From government to governance: Political steering in modern societies. In Governance of integrated product policy (pp. 18-25). Routledge.

31.Merchant, Altaf, John B. Ford, and Gregory M. Rose (2011), "How Personal Nostalgia Influences Giving to Charity," Journal of Business Research, 64 (June), 610-616.

32. Montenegro, T., \& Bras, F. A. (2015). Audit quality: Does gender composition of audit firms matter? /La influencia de la composición de género de las firmas auditoras en la calidad de auditoría. Revista Española De Financiación y Contabilidad,44(3), 264-297.

33.Muhammadi, A. H. (2016). Three essays on political connections, financial reporting, and auditing: evidence from Indonesian listed companies: a thesis presented in partial fulfilment of the requirements for the degree of Doctor of Philosophy in Accountancy at Massey University, Albany, New Zealand (Doctoral dissertation, Massey University).

34.Obeid, A. O., \& Abdelnur, A. (2018). An evaluation of objectivity and competence of internal audit departments in sudanese government units. International Journal of Economics and Financial Issues, 8(3), 9-16. Retrieved from https://search. proquest.com/docview/2056362385? accountid=42729.

35.Orr L. \& Hauser W. (2008). A Re-inquiry of Hofstede's Cultural Dimension: a call for $21^{\text {st }}$ Century Cross-Cultural Research. The Marketing Management Journal Volume 18, issue 2, pp. 1-19. 
36.Peng, Y. L. (2010). The empirical study on corporate governance, audit market and audit quality (Order No. 10382905). Available from ProQuest Dissertations \& Theses A\&I. (1868792779). Retrieved from https://search.proquest.com/docview/1868792779?accountid=42729.

37.Salleh and Jasmani, (2014). Audit Rotation and Audit Report: Empirical Evidence from Malasian PLCs over the Period of the Year. Procedia-Social and Behavioral Sciences 145, 40-50.

38.Sikka, P. (2009). Financial crisis and the silence of the auditors. Accounting, Organizations and Society, 34(6-7), 868-873.

39.Svanberg, J., \& Öhman, P. (2013). Auditors' time pressure: Does ethical culture support audit quality? Managerial Auditing Journal,28(7), 572-591. doi: http://dx.doi.org/10.1108/MAJ-10-20120761. 